\title{
Assessment of some prescribed drugs in the management of COVID-19 on the survival function: A preliminary report from a single center in Iraq
}

\author{
Marwan Salih AL-NIMER 1 * (D), Talar Ahmad MERZA 2 (D) \\ 1 Department of Pharmacology, Faculty of Medicine, Diyala University, Baqubah 32001, Iraq. \\ 2 Department of Clinical Pharmacy, Faculty of Pharmacy, Hawler Medical University, Erbil 44001 Erbil, Iraq. \\ * Corresponding Author. E-mail: alnimermarwan@ymail.com (M.S.); Tel. +964-790-260 0291.
}

Received: 22 May 2021 / Revised: 07 August 2021/ Accepted: 05 September 2021

\begin{abstract}
Several medications are used to treat the patients and to control the spread of the disease. Some of these drugs proved to be harmful besides drug-drug interactions can be occurred particularly in old-age groups or patients with chronic diseases. This study aimed to investigate the effects of several drugs on the survival outcome of COVID19 patients hospitalized in a single medical center in Erbil, Iraq. 204 patients (128 men and 76 women) with COVID-19 were recruited from the West Erbil Emergency hospital between August 10 and November 20, 2020. The primary outcome measures were the survival rate during the course of illness taking into consideration the number and the generic name of prescribed drugs, the percentage of saturated blood oxygen (sPO2), and the age. A total number of sixty-four patients died. Non-survivors are characterized by having a significantly lower percentage of sPO2 and used a significantly high mean value of a number (4-5) of drugs during the course of treatment. The percentage of nonsurvivors who used fluoroquinolones was significantly higher than the corresponding percentage of survivors ( 37.5 vs 21.4, $\mathrm{p}=0.016)$. The cumulative odds ratio $(>1.0)$ was observed significantly $\left(\chi^{2}=6.286, \mathrm{p}=0.012\right)$ in patients who used five-drug items despite the $\mathrm{sPO} 2 \geq 90 \%$. We conclude that drug combinations of more than three drugs are harmful in old-age group patients, and dexamethasone, carbapenems, and fluoroquinolones should be not prescribed as empiric therapy.
\end{abstract}

KEYWORDS: COVID-19; survival; antivirals; dexamethasone; antibiotics.

\section{INTRODUCTION}

COVID-19 is a pandemic disease caused by a positive-sense single-stranded RNA virus [1,2]. A new strain of coronavirus is the causative agent of COVID-19 which is the outbreak that started in Wuhan-China in December 2019 [3]. COVID-19 is an atypical respiratory disease with multiple complications that progressed to respiratory failure, renal failure, and death. Old-age and obese people, patients with cardiovascular, respiratory, and endocrine diseases are more susceptible to get coronavirus (CoV) infection [4]. Several medications are used to survive the patients and to control the spread of the disease. Anti-viral agents including a combination of lopinavir and ritonavir, remdesivir, favipiravir, arbidol, ribavirin, and so on are used with discrepancy results [5-8]. Dexamethasone as an adjunct medicine to patients receiving respiratory support (oxygen therapy and/or mechanical ventilation) reduced the mortality rate of hospitalized COVID19 patients [9]. Heparin (an injectable anticoagulant) is indicated in COVID-19 to overcome the coagulation disorder observed with CoV-infection [10]. It has been found that heparin therapy associated with a significantly lower mortality rate in COVID-19 patients when the data were adjusted for many confounding factors e.g. age, sex, hyperpyrexia, low saturated blood oxygen, and using the antivirals [11]. Azithromycin is a macrolide antibiotic with the antiviral property was indicated in the management of COVID-19 [12]. Azithromycin alone or in combination with hydroxychloroquine reduced the hospitalized inpatient mortality rate by $4 \%$ and $6.3 \%$, respectively [13]. In addition, varieties of antimicrobials are used as monotherapy or in combination to control the secondary bacterial infections are also prescribed [14]. Some authors believed that fluoroquinolones are useful in the management of $\mathrm{CoV}$-associated pneumonia because fluoroquinolones are indicated to severe community-acquired pneumonia and have multiple immunomodulatory effects characterized by suppressing the pro-inflammatory cytokines [15]. Bacterial co-infections in COVID-19 were

How to cite this article: Al-Nimer MS, Merza TA. Assessment of some prescribed drugs in the management of COVID-19 on the survival function: A preliminary report from a single center in Iraq. J Res Pharm. 2021; 25(6): 866-871. 
reported without explanation and usually responded to a broad or extended-spectrum of antibiotics [16]. The severity of the COVID-19, the patients using multiple drug therapy, and evidence of concomitant illnesses may collectively affect the mortality rate. Therefore, this study hypothesized that drugs prescribed in the management of the COVID-19 showed different effects on the clinical outcome in hospitalized patients. This cross-sectional observational study aimed to investigate the effects of using several drug modalities on the survival outcome of COVID-19 patients hospitalized in a single medical center in Erbil, Iraq.

\section{RESULTS}

Table 1 shows that $68.6 \%$ of patients were clinically recovered from illnesses, while $31.4 \%$ of patients died. There are no significant differences between Group I and II in the gender distribution or the mean of the age. Group I patients was characterized by having a significantly lower percentage of sPO2 and used a significant high mean value of a number of categorized drugs during the course of treatment.

Table 1. Characteristics of the participants.

\begin{tabular}{lccc}
\hline \multicolumn{1}{c}{ Variables } & $\begin{array}{c}\text { Group I } \\
\text { (non-survived) }\end{array}$ & $\begin{array}{c}\text { Group II } \\
\text { (survived) }\end{array}$ & p-value \\
\hline Number & $64(31.4 \%)$ & $140(68.6 \%)$ & \\
Age & $60.9 \pm 14.8$ & $57.1 \pm 14.0$ & 0.077 \\
Gender (men: women) & $45: 19$ & $83: 57$ & \\
sPO2 & $75.3 \pm 12.0$ & $83.9 \pm 10.0$ & $<0.001$ \\
Number of categorized drugs & $3.70 \pm 0.94(4.0)$ & $3.33 \pm 1.03(3.0)$ & 0.012 \\
\hline
\end{tabular}

The results are expressed as number (\%) and mean \pm SD (median). P-value was calculated using independent two-sample t-test, difference between percentages test, and Chi-square test.

Table 2 shows that Group II patients used more frequently 1-3 drugs, while Group I patients used more frequently 4-5 drugs. Two survived patients have used six drugs. Table 3 showed that the more frequent use of fluoroquinolones was significantly associated with death. Also, patients using carbapenems or glucocorticosteroids are more non-significantly non-survived.

Table 2. Distribution of patients according to the number of prescriptions.

\begin{tabular}{cccccc}
\hline Number of drugs & $\begin{array}{c}\text { Group I } \\
\text { (non-survived) }\end{array}$ & $\begin{array}{c}\text { Group II } \\
\text { (survived) }\end{array}$ & Total & $\boldsymbol{\chi}^{\mathbf{2}}$ & p-value \\
\hline 1 & $1(1.6)$ & $7(5.0)$ & $8(3.9)$ & 1.337 & 0.248 \\
2 & $5(7.8)$ & $18(12.9)$ & $23(11.3)$ & 1.134 & 0.287 \\
3 & $19(29.7)$ & $55(39.3)$ & $74(36.3)$ & 0.846 & 0.358 \\
4 & $26(40.6)$ & $44(31.4)$ & $70(34.3)$ & 1.642 & 0.200 \\
5 & $13(20.3)$ & $14(10.0)$ & $27(13.2)$ & 4.039 & 0.045 \\
6 & $0(0.0)$ & $2(1.4)$ & $2(1.0)$ & 0.900 & 0.343 \\
\hline
\end{tabular}

The results are expressed as number (\%). P-value was calculated using difference between percentages test, and Chisquare $\left(X^{2}\right)$ test.

Table 3. Distribution of patients according to the prescribed drug categories.

\begin{tabular}{lccccc}
\hline \multicolumn{1}{c}{ Variables } & $\begin{array}{c}\text { Group I } \\
\text { (non-survived) }\end{array}$ & $\begin{array}{c}\text { Group II } \\
\text { (survived) }\end{array}$ & Total & $\boldsymbol{X}^{\mathbf{2}}$ & p-value \\
\hline Antivirals & $23(35.9)$ & $57(40.7)$ & 80 & 0.423 & 0.516 \\
Glucocorticosteroids & $57(89.1)$ & $111(79.3)$ & 168 & 2.891 & 0.089 \\
Anticoagulants & $55(85.9)$ & $119(85.0)$ & 174 & 0.028 & 0.867 \\
Azithromycin & $14(21.9)$ & $30(21.4)$ & 44 & 0.006 & 0.936 \\
Fluroquinolones & $24(37.5)$ & $30(21.4)$ & 54 & 5.823 & 0.016 \\
Carbapenems & $40(62.5)$ & $70(50.0)$ & 110 & 2.749 & 0.097 \\
Cephalosporins & $21(32.8)$ & $52(37.1)$ & 73 & 0.352 & 0.553 \\
\hline
\end{tabular}

The results are expressed as number (\%). P-value was calculated using difference between percentages test, and Chisquare $\left(x^{2}\right)$ test.

Figure 1 shows the cumulative odds ratio $(>1.0)$ was observed significantly $\left(x^{2}=6.258, p=0.011\right)$ in patients with advanced age who used 3-5 drugs, while the cumulative odds ratio $(<1.0)$ was observed in patients who used 1-2 drugs of whatever age. Figure 2 shows the cumulative odds ratio $(>1.0)$ was observed significantly $(x 2=6.286, \mathrm{p}=0.012)$ in patients who used 5 drugs despite the $\mathrm{sPO} 2 \geq 90 \%$. 


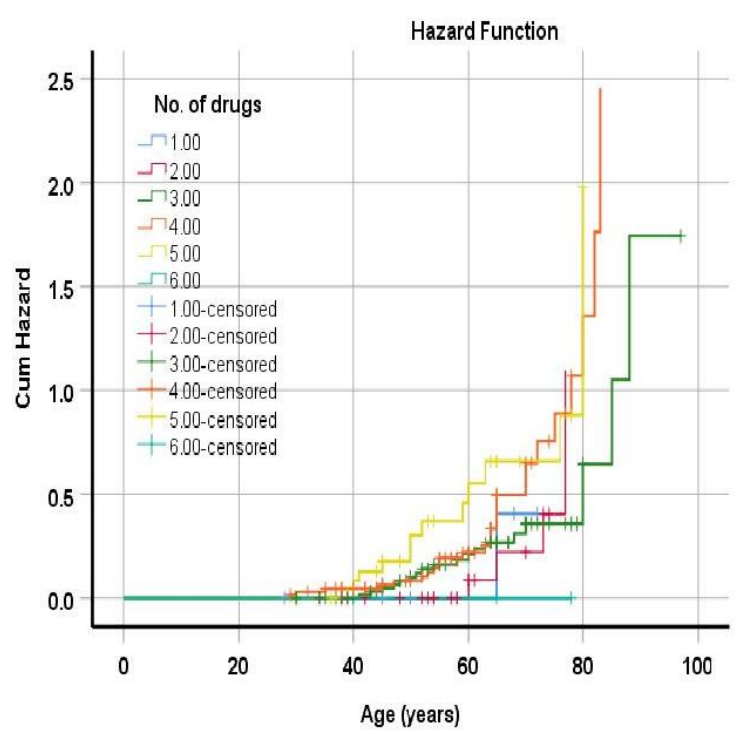

Figure 1. The cumulative odds ratio of non-survivors ( $n=64$ patients) compared with survivors ( $n=140$ patients; labeled as censored) based on the age and a number of medications (1-6). The cumulative odds ratio calculated by using Kaplan-Meier test and analyzed by Breslow (generalized Wilcoxon test).

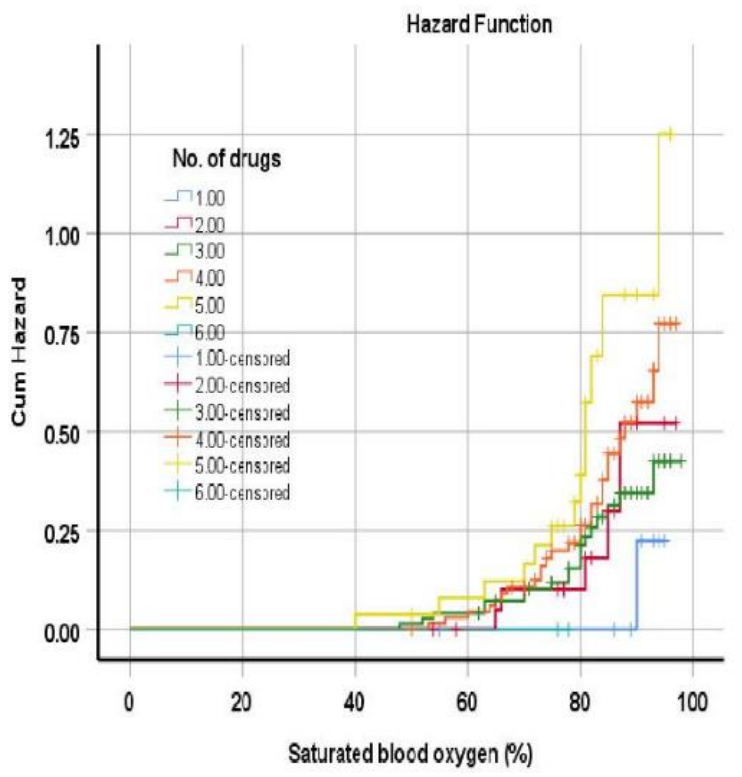

Figure 2. The cumulative odds ratio of non-survivors ( $n=64$ patients) compared with survivors $(n=140$ patients labeled as censored) based on the saturated blood oxygen (\%) and a number of medications (1-6).

\section{DISCUSSION}

The results of this study indicate that COVID-19 patients with a poor prognostic outcome are presented with significantly low saturated blood oxygen, and who used more frequent medical items, particularly fluoroquinolones. The management of COVID-19 in West Erbil Emergency hospital is usually symptomatic for mild and uncomplicated cases. Antiviral therapy, anticoagulant and dexamethasone are the cornerstone therapy for COVID-19 patients, which supplemented with different antibiotic regiemen according to the general health status of the patients. Several studies showed that advanced age is a predictor of the poorly prognostic outcome of COVID-19 patients. The results of this study confirmed previous studies that showed older age associated with an increased-odd (1.1, confidence intervals 1.03-1.17) in-hospital death [17]. The ratio of men: women in Group I is more than the corresponding ratio in Group II patients, which indicates that male sex is associated with in-hospital death [18]. A significant association between mortality and hypoxia can be attributed to the complications of $\mathrm{CoV}$ infection, including myocardial injury, cardiac arrhythmias, respiratory 
failure, cardiogenic shock, and so on [19]. De Smet et al (2020) found that polypharmacy was not an associated risk factor of in-hospital death, while this study finds that the percentage of non-survived patients are significantly used a higher number of medical items compared with survived patients [20]. The possible explanation of this discrepancy is related to the small sample size (81 patients; 19 non-survivors and 62 survivors), and the polypharmacy was not specified in the De Smet et al study [20]. Moreover, advanced age is a risk factor of death which acts synergistically with an increased number of medical items to increase the in-hospital death as shown in Figure 1. Furthermore, there is no association between hypoxia and the number of prescribed drugs as Figure 2 showed that the cumulative odds were higher in patients who used 4-5 drugs despite the percentage of blood oxygen saturation was of $>90 \%$. The possible explanation is due to the drugdrug interaction. Moreover, patients who used six drugs showed a lower percentage of poor outcome, which attributed to the drugs that counteract the complications e.g. using anticoagulants for deep venous thrombosis or using cephalosporins instead of fluoroquinolones. Therefore, scientific prescription of drugs of whatever their number could be helpful in the management of coronavirus infection.

Antivirals e.g. remdesivir improves the clinical symptoms and non-significantly reduces the percentage of un-survivors, which agreed with the Beigel et al study [21] who found that the mortality rate in patients who used remdesivir was $6.7 \%$ compared with $11.7 \%$ in patients treated with placebo by day 15 of treatment. The percentages of non-survivors are higher in patients treated with systemic glucocorticosteroids, carbapenems, and significantly with fluoroquinolones. Previous studies reported that dexamethasone reduced the mortality rate of severe Covid-illness that required oxygen therapy and/or invasive mechanical ventilation [9] while another study showed dexamethasone prescription is associated with increased mortality [18]. In our study, $82.4 \%$ (168 out of 204) of patients received glucocorticosteroids therapy without producing a significant effect on the poor outcome. The current study agreed with Liu et al study [22] who reported that antibiotics (carbapenems and fluoroquinolones) increased the mortality rate and the acute organ injury. This observation necessitates not using carbapenems and fluoroquinolones as empirical therapy for COVID-19 without evidence of bacterial infections. Moreover, carbapenems and fluoroquinolones have toxic effects on blood cells and the heart, respectively [23, 24]. Limitations of the study included a small sample size, patients recruited from single-center, and cardio-metabolic risk factors are not considered.

\section{CONCLUSION}

This study adds new information that antivirals have limited therapeutic effects while other medicines are harmful and of no benefit in the management of COVID-19. Combinations of 3-5 drugs are harmful in oldage group patients and dexamethasone and antibiotics (carbapenems and fluoroquinolones) should not be prescribed as empiric therapy.

\section{PATIENTS AND METHODS}

This cross-sectional study is carried at Hawler Medical University and coordinated by The West Erbil Emergency Hospital in the Erbil, Iraq. Patients were recruited from the hospital between August 10 and November 20, 2020. Hospitalized patients with confirmed COVID-19 were included regardless of their clinical features or the percentage of saturated blood oxygen. The diagnosis of COVID-19 was achieved by polymerase chain reaction (PCR) assays on the swabs obtained from the nasopharynx at the time of admission into the hospital. Patients with clinical features of upper respiratory tract infections and negative PCR-tests for CoV were excluded from the study. The Ethical and Scientific Board at the Ministry of the Health in the Erbil approved this study, and exempt the need for consent. The patients were randomly recruited from the hospital using a random numbers table according to the number of admission sheet records, regardless of their using the generic drug or the number of drugs. Patients treated with symptomatic medicines, including antipyretics, antitussives, antacids, diuretics, bronchodilators, multivitamins, and nutraceuticals...etc. and allopathic therapy including oxygen, intravenous fluids, and invasive mechanical ventilation were excluded from the analysis. The sample size was calculated using $\alpha$-coefficient (type II error) $=0.05, \beta$-coefficient (type I error) $=$ 0.2 , and power $=85 \%$ ). A total number of 204 patients (128 men and 76 women) with a median age of 59.5 years were assessed. The percentage of saturated blood oxygen (sPO2) was determined during the course of illness. The primary outcome is the survival function of patients using a drug as monotherapy or in combinations. These medicines are antivirals (favipiravir, remdesivir), glucocorticosteroids (dexamethasone [n=154], methylprednisolone [ $\mathrm{n}=11]$, hydrocortisone [ $\mathrm{n}=3]$ ), anticoagulants (heparin, low molecular weight heparin), azithromycin, carbapenems (meropenem, imipenem), cephalosporins (ceftriaxone, cefotaxime, cephalexin), and fluoroquinolones (ciprofloxacin, levofloxcin, moxifloxacin). The patients were categorized 
according to their clinical outcomes during the study period into Group I (non-survived) and Group II (survived).

\subsection{Statistical analysis}

The results are expressed as a number, percentage, median, and mean $\pm \mathrm{SD}$. The data was analyzed by using IBM SPSS Statistics Software version 24 (IBM Corp, Armonk, NY, USA). Differences between Group I and II were analyzed by Chi-square test for categorized data and independent two-sample two-tailed t-test, the difference between the percentages test. The cumulative odds ratio was calculated using the Kaplan Meier test analyzed by Breslow (Generalized Wilcoxon) test. A p-value of $\leq 0.05$ is a significant cutoff level.

Acknowledgements: The authors express their gratitude to the staff of The West Erbil Emergency Hospital for their unlimited cooperation.

Author contributions: Concept: M.S.AN.; Design: M.S.AN; Supervision: M.S.AN., T.A.M; Resources: M.S.AN., T.A.M; Materials: T.A.M; Data collection T.A.M; Analysis and Interpretation: M.S.AN; Literature Search M.S.AN; Writing: M.S.AN; Critical Reviews: M.S.AN., T.A.M.

Conflict of interest statement: The authors declared no conflict of interest in the manuscript.

Ethics committee approval: The Ethical and Scientific Board at the Ministry of the Health in the Erbil approved this study.

\section{REFERENCES}

[1] Sexton NR, Smith EC, Blanc H, Vignuzzi M, Peersen OB, Denison MR. Homology-based identification of a mutation in the coronavirus RNA-dependent RNA polymerase that confers resistance to multiple mutagens. J Virol. 2016; 90(16): 7415-7428. [CrossRef]

[2] Su S, Wong G, Shi W, Liu J, Lai ACK, Zhou J, Liu W, Bi Y, Gao GF. Epidemiology, genetic recombination, and pathogenesis of Coronaviruses. Trends Microbiol. 2016; 24(6): 490-502. [CrossRef]

[3] WHO Statement Regarding Cluster of Pneumonia Cases in Wuhan, China. [who.int/china/news/detail/09-01-2020who-statement-regarding-cluster-of-pneumonia-cases-in-wuhan-china]. Retrieved on 10 January 2020.

[4] Grasselli G, Greco M, Zanella A, Albano G, Antonelli M, Bellani G, Bonanomi E, Cabrini L, Carlesso E, Castelli G, Cattaneo S, Cereda D, Colombo S, Coluccello A, Crescini G, Forastieri Molinari A, Foti G, Fumagalli R, Iotti GA, Langer T, Latronico N, Lorini FL, Mojoli F, Natalini G, Pessina CM, Ranieri VM, Rech R, Scudeller L, Rosano A, Storti E, Thompson BT, Tirani M, Villani PG, Pesenti A, Cecconi M; COVID-19 Lombardy ICU Network. Risk factors associated with mortality among patients with COVID-19 in intensive care units in Lombardy, Italy. JAMA Intern Med. 2020; 180(10): 1345-1355. [CrossRef]

[5] Chen N, Zhou M, Dong X, Qu J, Gong F, Han Y, Qiu Y, Wang J, Liu Y, Wei Y, Xia J, Yu T, Zhang X, Zhang L. Epidemiological and clinical characteristics of 99 cases of 2019 novel coronavirus pneumonia in Wuhan, China: a descriptive study. Lancet. 2020; 395(10223): 507-513. [CrossRef]

[6] Li G, De Clercq E. Therapeutic options for the 2019 novel coronavirus (2019-nCoV). Nat Rev Drug Discov. 2020; 19(3): 149-150. [CrossRef]

[7] Sheahan TP, Sims AC, Leist SR, Schäfer A, Won J, Brown AJ, Montgomery SA, Hogg A, Babusis D, Clarke MO, Spahn JE, Bauer L, Sellers S, Porter D, Feng JY, Cihlar T, Jordan R, Denison MR, Baric RS. Comparative therapeutic efficacy of remdesivir and combination lopinavir, ritonavir, and interferon beta against MERS-CoV. Nat Commun. 2020; 11(1): 222. [CrossRef]

[8] Wang L, Yang R, Yuan B, Liu Y, Liu C. The antiviral and antimicrobial activities of licorice, a widely-used Chinese herb. Acta Pharm Sin B. 2015; 5(4): 310-315. [CrossRef]

[9] RECOVERY Collaborative Group, Horby P, Lim WS, Emberson JR, Mafham M, Bell JL, Linsell L, Staplin N, Brightling C, Ustianowski A, Elmahi E, Prudon B, Green C, Felton T, Chadwick D, Rege K, Fegan C, Chappell LC, Faust SN, Jaki T, Jeffery K, Montgomery A, Rowan K, Juszczak E, Baillie JK, Haynes R, Landray MJ. Dexamethasone in hospitalized patients with Covid-19. N Engl J Med. 2020; 384 (8): 693-704. [CrossRef]

[10] Miesbach W, Makris M. COVID-19: Coagulopathy, risk of thrombosis, and the rationale for anticoagulation. Clin Appl Thromb Hemost. 2020; 26: 1076029620938149. [CrossRef]

[11] Ayerbe L, Risco C, Ayis S. The association between treatment with heparin and survival in patients with Covid-19. J Thromb Thrombolysis. 2020; 50(2): 298-301. [CrossRef] 
[12] Tran DH, Sugamata R, Hirose T, Suzuki S, Noguchi Y, Sugawara A, Ito F, Yamamoto T, Kawachi S, Akagawa KS, Ōmura S, Sunazuka T, Ito N, Mimaki M, Suzuki K. Azithromycin, a 15-membered macrolide antibiotic, inhibits influenza $\mathrm{A}(\mathrm{H} 1 \mathrm{~N} 1)$ pdm09 virus infection by interfering with virus internalization process. J Antibiot (Tokyo). 2019; 72(10): 759-768. [CrossRef]

[13] Arshad S, Kilgore P, Chaudhry ZS, Jacobsen G, Wang DD, Huitsing K, Brar I, Alangaden GJ, Ramesh MS, McKinnon JE, O'Neill W, Zervos M; Henry Ford COVID-19 Task Force. Treatment with hydroxychloroquine, azithromycin, and combination in patients hospitalized with COVID-19. Int J Infect Dis. 2020; 97: 396-403. [CrossRef]

[14] Vaillancourt M, Jorth P. The unrecognized threat of secondary bacterial infections with COVID-19. mBio. 2020; 11(4): e01806-20. [CrossRef]

[15] Karampela I, Dalamaga M. Could respiratory fluoroquinolones, levofloxacin and moxifloxacin, prove to be beneficial as an adjunct treatment in COVID-19? Arch Med Res. 2020; 51(7): 741-742. [CrossRef]

[16] Gallacher SD, Seaton A. Meningococcal meningitis and COVID-19 co-infection. BMJ Case Rep. 2020; $13(8)$ : e237366. [CrossRef]

[17] Zhou F, Yu T, Du R, Fan G, Liu Y, Liu Z, Xiang J, Wang Y, Song B, Gu X, Guan L, Wei Y, Li H, Wu X, Xu J, Tu S, Zhang Y, Chen H, Cao B. Clinical course and risk factors for mortality of adult inpatients with COVID-19 in Wuhan, China: a retrospective cohort study. Lancet. 2020; 395(10229): 1054-1062. [CrossRef]

[18] Li X, Xu S, Yu M, Wang K, Tao Y, Zhou Y, Shi J, Zhou M, Wu B, Yang Z, Zhang C, Yue J, Zhang Z, Renz H, Liu X, Xie J, Xie M, Zhao J. Risk factors for severity and mortality in adult COVID-19 inpatients in Wuhan. J Allergy Clin Immunol. 2020; 146(1): 110-118. [CrossRef].

[19] Zhu H, Rhee JW, Cheng P, Waliany S, Chang A, Witteles RM, Maecker H, Davis MM, Nguyen PK, Wu SM. Cardiovascular Complications in Patients with COVID-19: Consequences of Viral Toxicities and Host Immune Response. Curr Cardiol Rep. 2020; 22(5): 32. [CrossRef]

[20] De Smet R, Mellaerts B, Vandewinckele H, Lybeert P, Frans E, Ombelet S, Lemahieu W, Symons R, Ho E, Frans J, Smismans A, Laurent MR. Frailty and mortality in hospitalized older adults with COVID-19: Retrospective Observational Study. J Am Med Dir Assoc. 2020; 21(7): 928-932.e1. [CrossRef]

[21] Beigel JH, Tomashek KM, Dodd LE, Mehta AK, Zingman BS, Kalil AC, Hohmann E, Chu HY, Luetkemeyer A, Kline S, Lopez de Castilla D, Finberg RW, Dierberg K, Tapson V, Hsieh L, Patterson TF, Paredes R, Sweeney DA, Short WR, Touloumi G, Lye DC, Ohmagari N, Oh MD, Ruiz-Palacios GM, Benfield T, Fätkenheuer G, Kortepeter MG, Atmar RL, Creech CB, Lundgren J, Babiker AG, Pett S, Neaton JD, Burgess TH, Bonnett T, Green M, Makowski M, Osinusi A, Nayak S, Lane HC; ACTT-1 Study Group Members. Remdesivir for the Treatment of Covid-19 - Final Report. N Engl J Med. 2020; 383(19): 1813-1826. [CrossRef]

[22] Liu C, Wen Y, Wan W, Lei J, Jiang X. Clinical characteristics and antibiotics treatment in suspected bacterial infection patients with COVID-19. Int Immunopharmacol. 2021; 90: 107157. [CrossRef]

[23] Oka S, Shiragami H, Nohgawa M. Intravascular hemolytic anemia in a patient with antibodies related to meropenem. Intern Med. 2015;54(10): 1291-1295. [CrossRef]

[24] Patel N, Hatley O, Berg A, Romero K, Wisniowska B, Hanna D, Hermann D, Polak S. Towards Bridging Translational Gap in Cardiotoxicity Prediction: an Application of Progressive Cardiac Risk Assessment Strategy in TdP Risk Assessment of Moxifloxacin. AAPS J. 2018; 20(3): 47. [CrossRef] 